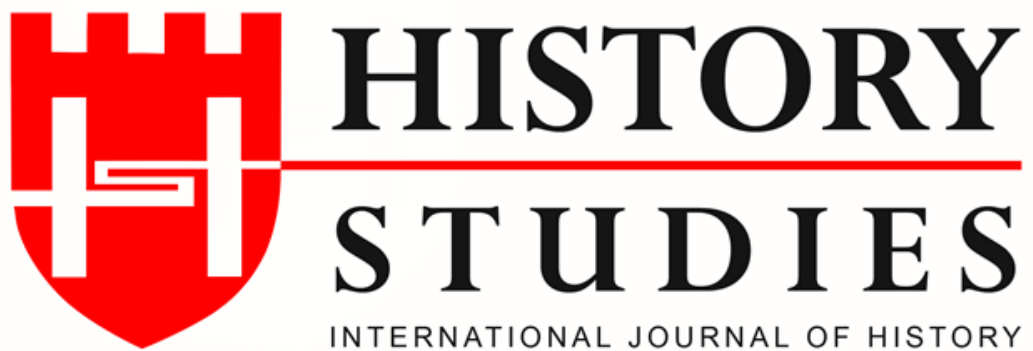

ISSN: 13094173 / (Online) 1309 - 4688 (Print)

Volume: 13, Issue: 4, August 2021

www.historystudies.net

\title{
THE WARS OF DOMINION BETWEEN SELEUCID AND PARTHIAN KINGDOMS IN MESOPOTAMIA
}

\section{Seleukos ve Parth Krallıkları'nın Mezopotamya'daki Egemenlik Savaşları}

Doç. Dr. Nurgül Yıldırım

Hatay Mustafa Kemal Üniversitesi nurgulyildirim0631@gmail.com

ORCID ID: 0000- 0002-4692-2823

\section{Doktora Öğrencisi Meltem Temizkan}

Kahramanmaraş Sütçü İmam Üniversitesi mltm92.tmzkn@gmail.com ORCID ID: 0000- 0002-4692-2823

Makale Türü-Article Type Geliş Tarihi-Received Date Kabul Tarihi-Accepted Date DOI Number
Araştırma Makalesi-Research Article 14.06.2021

12.08.2021

10.9737/hist.2021.1038

Atıf-Citation:

Nurgül Yıldırım- Meltem Temizkan, "The Wars of Dominion Between Seleucid and Parthian Kingdoms in Mesopotamia ", History Studies, 13/4, Ağustos 2021, s. 1357-1368. 

HISTORY STUDIES

Uluslararası Tarih Araştırmaları Dergisi

International Journal of History

13/4, Ağustos - August 2021

1357-1368

Araştırma Makalesi

\title{
THE WARS OF DOMINION BETWEEN SELEUCID AND PARTHIAN KINGDOMS IN MESOPOTAMIA
}

Seleukos ve Parth Krallıkları'nın Mezopotamya'daki Egemenlik Savaşları

\author{
Doç. Dr. Nurgül Yıldırım
}

\section{Doktora Öğrencisi Meltem Temizkan}

\section{Öz}

Erken Hellenistik Dönemin Mezopotamya coğrafyasındaki hâkim gücü olan Seleukoslar, kurucu kralları I. Seleukos Nikator'un ardından Doğu topraklarının idaresinde yetersiz kalmaya başlamıștır. Bu yetersizlik özellikle, Eski İran coğrafyasında Persler'in ardından kurulan merkeziyetçi yapılardan biri olan Parthlar'ın güçlenme ve kendilerini Mezopotamya'da siyasi açıdan var etme çabalarıyla ilişkili olmuştur. Parthlar'ın Seleukoslar döneminde Pers Eyaleti'nin önemli merkezlerinden biri olarak kabul edilmesi ve burada Seleukoslar tarafından atanan valiler tarafından idare edildiği süreçte siyasi açıdan teşkilatlanmaya başladıkları anlaşılmıştır. Parthlar'ın MÖ 205 yılında III. Antiokhos Megas'a karşı gösterdikleri büyük direniş ve bu direniş sonucunda Seleukoslarla yapılan antlaşma Parthlar'ın Doğu'da bölgesel bir siyasi güç olarak tescillenmelerini sağlamıștır. Seleukoslar'a karșı bu kazanımlarını sürdürme çabası içerisindeki Parthlar, VII. Antiokhos döneminde değișen siyasi dengeler ve iç isyanlar nedeniyle MÖ 130/129 yıllarında Seleukoslar'ın Babil ve İran topraklarından çekilmeleriyle, siyasi etkinlik alanlarını genişletme firsatı yakalamıştır. Seleukoslar'ın Batı toprakları için Roma ile mücadele ettiği ve bu mücadelesini kaybettiği dönemde ise Parthlar Mezopotamya'da güçlü bir krallık olarak Seleukoslar'ın ardından Roma ile mücadele etmek durumunda kalmıştır. Parthlar ve Seleukoslar'ın Mezopotamya coğrafyasındaki var olma mücadelelerinin irdelenmesi ve kronolojik açıdan incelenmesinin amaçlandığı bu çalışmada döneme ilişskin antik kayıtlar ve modern literatürden yararlanılmıştır.

Anahtar Sözcükler: Hellenistik Dönem, Parth Eyaleti, Phrataphernes, Arşaklar, Seleukeia Tigris.

\section{Abstract}

The Seleucids, the dominant power in the Mesopotamian geography of the Early Hellenistic Period, began to fall short in the administration of the Eastern lands after their founding king, Seleucus Nicator I. This inadequacy was especially related to the efforts of the Parthians, one of the centralist structures established after the Persians in Ancient Iran, to gain strength and establish themselves politically in Mesopotamia. It has been understood that the Parthians began to be politically organized during the Seleucid period when the Persian State was accepted as one of the important centers and administered by the governors appointed by the Seleucids. The great resistance of the Parthians against Antiochus Megas III in $205 \mathrm{BC}$ and the agreement made with the Seleucids as a result of this resistance enabled the Parthians to be registered as a regional political power in the East. . In an effort to maintain these gains against the Seleucids, the Parthians had the opportunity to expand their political sphere of activity with the withdrawal of the Seleucids from Babylon and Iran in 130/129 BC due to the changing political balances and internal rebellions during the reign of Antiochus VII. In the period when the Seleucids struggled with Rome for the western lands and lost this struggle, the Parthians had to struggle with Rome as a powerful kingdom in Mesopotamia after the Seleucids. In this study, which aims to chronologically examine the existence struggles of the Parthians and Seleucids in Mesopotamian geography, ancient records of the period and modern literature were used.

Keywords: Hellenistic Period, Satrapy of Parthia, Phrataphernes, Arsacid, Seleuceia Tigris. 


\title{
Introduction
}

The borders of the Hellenistic Seleucid Kingdom, which was founded by Seleucus Nicator I, who was one of the commanders of the Macedonian King Alexander the Great in 312/311 $\mathrm{BC}$, also included the Parthia (Northeast Iran) region. ${ }^{1}$ The domination of this great state, which stretched from the Aegean Sea to almost India ${ }^{2}$, over the Parthia region was seen as a factor that strengthened its sovereignty in the Eastern lands. The political records of the nomadic Parths (Parn/Parni/Aparni) ${ }^{3}$, who spread almost all over Mesopotamia from Iran and its north, were first recorded in the Assyrian king annals. In the records of the Assyrian King Asarhaddon's expedition, including the region south of the Caspian Sea dated to 674-673 BC, the Parthian region was referred to as "Partukka and Partakka". When Persian King Cyrus II (590-529 BC) captured this region, he transformed it into a political structure dependent on the Persian Satrap. ${ }^{4}$

The Parthians fought against Alexander the Great in the Battle of Gaugamela (331 BC) in Arbela (Erbil) in the Eastern Campaign (336-323 BC) instigated by Alexander the Great against the Persians. ${ }^{5}$ However, Alexander the Great's advance to the eastern lands and the defeat of Persian King Darius III raised concerns in Persian satraps. At this point, the Bactrian satrap Bessos cut off the road from Khorasan to Bactria against Alexander the Great, whereas the Parthian satrap Phrataphernes departed for Hyrcania (Gurgan) with Nabarzanes, one of the Persian nobles. The plan of Phrataphernes and Nabarzanes was to cross from Hyrcania to Bactria and unite with Bessos. In this context, the other satraps planned to act together with Bessos to defend the Persian Kingdom against Alexander the Great and then to share the state among themselves. However, Satrap of Parthia Phrataphernes, Satrap of Areia (Aria/Arya) ${ }^{6}$ Satibarzanes and Satrap of Drangiana/Sarangia ${ }^{7}$ Barsaentes conceived that their reign would be in jeopardy if they moved towards Bactria to unite against Macedonians under the command of Bessos. Thereupon, Phrataphernes and Nabarzanes opted to stay in Hyrcania. Satibarzanes went to Areia, whereas Barsaentes moved to Drangiana. ${ }^{8}$ The Parthian satrap Phrataphernes surrendered to Alexander the Great upon his arrival at Hyrcania. ${ }^{9}$ Subsequently, Alexander the Great appointed Parthian-origin Amminaspes as the satrap to the region. Alexander the Great

\footnotetext{
${ }^{1}$ Josef Wiesehöfer, "Fars under Seleucid and Parthian Rule", The Age of the Parthians The Idea of Iran, Vol. 2, Ed. V. S. Curtis ve S. Stewart, I.B. Tauris Publishing, London, New York 2007, p. 39.

2 Susan Sherwin White- Amélie Kuhrt, From Samarkhand to Sardis: A New Approach to the Seleucid Empire, University of California Press, Berkeley-Los Angeles 1993, p. 7-14.

${ }^{3}$ As the nomadic Parnies began to settle in the Parthiene/Parthava lands led by Arsaces, they were called Parth. Edward Dabrowa, "The Arsacid Empire", Oxford Handbook of Iranian History, Ed. Touraj Daryaee, Oxford University Press, Oxford 2012, p. 168. In addition, it is stated that the Parths were forced to migrate by the Scythians and their name means exiled in the Scythian language. Justin, Epitome, 41. 1.

${ }^{4}$ Neilson Carel Debevoise, A Political History of Parthia, The University of Chicago Press, Chicago 1938, p. 2-4; Nurgül Yıldırım, “Çivi Yazılı Tarihçelerde Babil'in Doğulu Son Hâkimleri Parthlar”, 3. Uluslararası Multidisipliner Sosyal Bilimler Kongresi, 04-06 May1s 2021, Ankara 2021, p. 325.

5 Arrian, Anabasis, 3. 11.; George Rawlinson, The Sixth Great Oriental Monarchy or The Geography, History, \& Antiquities of Parthia, Longmans, Green \& Co., London 1873, p. 28.

${ }^{6}$ South of Areia Margiana/ Merv/Turkmenistan designated as present-day Herat, bordering Parthia. George Rawlinson, Ibid., 1873, p. 10-11. This center has also been defined as the region extending westward along the Arius (Hari) River, originating from the south side of the Paropamisus (Hindukuş/Hindikuş) Mountain. George Rawlinson, Parthia, T. Fisher Unwin London 1893, p. 20.

${ }^{7}$ Drangiana/Sarangia (Seistan) is adjacent to Areia (Herat) to the south and is defined as a region that covers an area larger than Aria. It is surrounded by Lake Hamun in the north, the Great Iranian Desert in the west and the Kash River in the east. George Rawlinson, Ibid., 1893, p. 20.

8 Johann Gustav Droysen, Büyük İskender Tarihi, Çev: Prof. Dr. Bekir Sıtkı Baykal, Panama Yayınları, Ankara 2020, p. 348-349.

${ }_{9}$ Arrian, Anabasis, 3. 23.
}

\author{
History Studies \\ www.historystudies.net
}


assigned Pythophanes' son Tlepolemus from the royal guard to Parthia in order to oversee the development of events in the region. ${ }^{10}$

After the death of Alexander the Great in 323 BC, Philippos/Philotas was appointed to Parthia as satrap in accordance with the meeting held in $321 / 320 \mathrm{BC}$ by his commanders in Triparadeisos/Triparadisus (north of Mount Lebanon) near the Orontes (Asi) River in Northern Syria. ${ }^{11}$ Parthia, which was subordinated to Stanasor, Satrap of Bactria as of $316 \mathrm{BC}^{12}$, came under the rule of Seleucus, one of the commanders of Alexander the Great, after 312/311 BC. This situation arose upon Seleucus capture of Babylonia, Media and Susiana and his establishing the Seleucid Dynasty. Following his domination in Mesopotamia, Seleucus, who expanded his dominance in the Eastern lands, made Parthia a province of his dynasty. ${ }^{13}$

\title{
1.The Parthian Independence Process and Antecedent Relations with the Seleucid Kingdom
}

During the reign of Seleucid King Antiochus Soter I (281-261 BC), Andragoras (PhereclesAgathocles) ${ }^{14}$ was appointed as the administrator of the Parthia Satrapy, which was united with Hyrcania. However, the struggles of the Seleucids with another Hellenistic kingdom, the Ptolemies (Egypt) became more frequent starting from the time of Antiochus Theos II. (261-246 $\mathrm{BC}$ ), and the Seleucids began to lose control over the satraps later on. ${ }^{15}$ This loss of control first manifested itself in the Satrapy of Bactria, and Diodotus, who had been appointed governor of Bactria by the Seleucids, rebelled in $250 \mathrm{BC}$ and declared his independence. ${ }^{16}$ Affected by this situation, the Satrap of Parthia Andragoras rebelled against the Seleucids but could not gain full independence. ${ }^{17}$

During the reign of Seleucus Callinicus II (246-227/225 BC), the struggles with the Ptolemaic (Egyptian) Dynasty caused the Seleucids to lose power. ${ }^{18}$ Within the scope of these struggles, Ptolemy King Ptolemy Philadelphus III's invasion of Mesopotamia ${ }^{19}$ (247/246-245 BC) provided the appropriate ground for Parthian expansion in the East in 247/246 BC. ${ }^{20}$ Thus, under the leadership of two brothers, Arsaces and Tridad/Tiridates, the Parnis, who set off from the Oxus (Ceyhun) River region, rebelled against the Parthian Satrap Andragoras. ${ }^{21}$ Following the rebellion, the Satrap of Parthia Andragoras was killed. ${ }^{22}$ Arsaces founded the Kingdom of

${ }^{10}$ Arrian, Anabasis, 3. 22; Droysen, İbid., p. 349.

${ }^{11}$ Justin, Epitome, 13. 4; Debevoise, İbid., p. 7; Mehmet Ali Kaya, Türkiye’nin Eskiçă̆ Tarihi-III- Hellenistik Dönem, Bilge Kültür-Sanat Yayınları, İstanbul 2019, p. 76.

12 Justin, Epitome, 41. 4. 1.

13 Appian., Syriake, 55; George Rawlinson, Ibid., 1873, p. 32-33; Elias Bickerman, "The Seleucid Period", The Cambridge History of Iran, 3/1, Ed. Ehsan Yarshater, Cambridge University Press, Cambridge 1983, p. 4; Sherwin White- Kuhrt, Ibid., p. 11.

${ }^{14}$ The name of the Satrap of Parthia is also known as Pherecles or Agathocles. For details, see, Jeffrey D. Lerner, The Impact of Seleucid Decline on the Eastern Iranian Plateau: The Foundations of Arsacid Parthia and Graeco-Bactria, Franz Steiner Verlag, Stuttgart 1999, p. 18.

${ }^{15}$ Richard Nelson Frye, The History of Ancient Iran, C. H. Becksche, Verlagsbuchhandlung, München 1983, p. 168.

16 George Rawlinson, The Bactrian Empire Under the Greek Dynasties: Bactria from the Earliest Times to the Extinction of Bactrio-Greek Rule in the Punjab, Cambridge 1909, p. 48; William Woodthorpe Tarn, The Greeks in Bactria \& India, Cambridge, University Press, London 1938, p. 72.

${ }^{17}$ George Rawlinson, Ibid., 1909, p. 48.

${ }^{18}$ Appian., Syriake, 65.

${ }^{19}$ The region passed into the hands of the Ptolemies between the Seleucid and Ptolemaic kingdoms during the Third Syrian War/Laodicean War in 246-241 BC. The region came under Seleucid rule again in 245 BC., due to internal turmoil in Egypt. Nurgül Yıldırım-Meltem Temizkan, "Seleukoslar Döneminde Yaşanan Suriye Savaşları Üzerine Bir Değerlendirme”, Mustafa Kemal Üniversitesi Sosyal Bilimler Enstitüsü Dergisi, 14, 39, 2017, p. 124. For detailed information on the war, see, John D. Grainger, The Syrian Wars, Leiden, Boston, Brill 2010, p. 153-171.

${ }^{20}$ Appian., Syriake, 65; Nurgül Yıldırım, İbid., 2021, p. 326.

${ }^{21}$ Debevoise, Ibid., p. 9.

${ }^{22}$ Frye, Íbid., p. 207; Lerner, Ibid., p. 18.

\author{
History Studies \\ www.historystudies.net
}


Arsaks/Parthia in Asaak (Arshakia), north of Mount Kopet. ${ }^{23}$ Thereupon, although the Parthians did not gain full independence, they started their own political period from 250-248/247 BC to $224 \mathrm{AD}^{24}$ The expansion policy, which was tried to be implemented by the Parthians, first started over its neighbors and continued through the Seleucid lands after consolidating its dominance in the east. ${ }^{25}$

The governance of the Parthians after Arsaces was taken over by his brother Tiridates. ${ }^{26}$ Tiridates ended the sovereignty of the Seleucid Dynasty in Hyrcania region. After capturing Hyrcania, he built castles there and declared the city of Arshak/Ars(h)/Ashk (Ashgabat/Turkmenistan) as the capital. ${ }^{27}$ The Ankyra/Brothers Battle (240/239-237/236 BC) between Seleucus Callinicus II and his brother Antiochus Hierax II (246-226 BC) for the throne and the sovereignty fight of the Seleucids ${ }^{28}$ with the Galatians in Asia Minor facilitated the progress of the Parths. ${ }^{29}$ However, Seleucus Callinicus II organized an expedition to the East ${ }^{30}$ in $237 \mathrm{BC}$ in order to stop the advance of the Parthians. ${ }^{31}$ As a result of this expedition, the Parnis had to retreat to the Chorasmia (Khorezm) region. ${ }^{32}$ After a while, Seleucus Callinicus II left the lands he had captured to the Parths and had to retreat due to the rebellion in Antioch, the center of his kingdom. ${ }^{33}$ As a result, the Parnis took advantage of the turmoil to turn the control in their favor $^{34}$ and established new centers (Hekatompylos/Shar-e Qumis) ${ }^{35}$ for themselves.

During the reign of Seleucus King Antiochus Megas III (223-187 BC), the Seleucids were exposed to the rebellion of Molon, the governor of Media, in the East between 222-220 BC. ${ }^{36}$ In

${ }^{23}$ Kaya, İbid., p. 421.

${ }^{24}$ Edwyn Robert Bevan, The House of Seleukos, Vol. 1, Edward Arnold Publisher, London 1902, p. 284-285; Debevoise, Ibid., p. 9. The period of the emergence of the Parnis as a political power is controversial. It is thought that the Parnis rebelled against Andragoras in $238 \mathrm{BC}$. It is mentioned that the Parnies rebelled against Androgoras in $238 \mathrm{BC}$ and they were successful in this period. They gained political power by taking advantage of the authority vacuum arising from the struggle of the Seleucids with the Galatians. Malcolm A. R. Colledge, The Parthians, Thames and Hudson, London 1967, p. 24; Adam D. H. Bivar, "The Political History Of Under The Arsacids", The Cambridge History of Iran, 3/1, Ed. Ehsan Yarshater, Cambridge University Press, Cambridge 1983, p. 28; Özgür Kahraman, Eskiçağ Tarihinde Parthlar, (İstanbul Üniversitesi Sosyal Bilimler Enstitüsü, Master's Thesis), İstanbul 2002 , p. 36.

${ }^{25}$ Maria Brosius, The Persians, by Routledge, New York 2006, p. 84; Nefel Delil, Roma-Part Savaşları Işı̆ğında Doğu Siyaseti ve Toprak-Sınır Mücadeleleri, (Dokuz Eylül Üniversitesi Sosyal Bilimler Enstitüsü, Master’s Thesis), İzmir 2018 , p. 47.

${ }^{26}$ It is known that the name Arsaces was used as a dynasty name in the Parthian Kingdom and the Parths were also called Arsaces. Brosius, İbid., p. 84. It has been argued that Tiridates, became king after Arsakes was called Arsakes and that Tiridates and Arsakes II were the same king. George Rawlinson, Ibid., 1873, p. 45. Tridates was succeeded by his son Arsaces II in 217 BC. For details, see, Dabrowa, Ibid., p. 169.

${ }^{27}$ Homa Katouzian, The Persians: Ancient, Medieval and Modern Iran, Yale University Press, New York 2010, p. 41; Kaya, Ibid., p. 421.

${ }^{28}$ Bevan, İbid., p. 192-203.

${ }^{29}$ Rolf Strootman, "The Coming of the Parthians: Crisis and resilience in Seleukid Iran in the reign of Seleukos II", The Seleukid Empire, 281-222 BC: War Within the Family, Ed. K. Erickson, Classical Press of Wales, Swansea 2018, p. 130.

${ }^{30}$ Regarding the Eastern campaigns that Seleucus Callinicus II made during his reign, Lerner claimed that Seleucus Callinicus II went on two Eastern Campaigns (236/235 BC-229/228 BC) and failed. Lerner, Ibid., p. 36.

${ }^{31}$ Colledge, Ibid., p. 28; Bivar, Ibid., p. 28.

32 Brosius, İbid., p. 85; Serhat Pir Tosun, Antik Çă̆’da Doğu-Batı Mücadelesi Kapsamında Roma-Part Illişkileri, (Uludağ Üniversitesi Sosyal Bilimler Enstitüsü, Master's Thesis), Bursa 2020, p. 15-16. Strootman, stated that Arsaces I was found in Parthia during Seleucus Callinikos II's Eastern Campaign and he was fought against. Strootman, Ibid., p. 130.

${ }^{33}$ Glanville Downey, Ancient Antioch, Princeton University Press. New Jersey 1963, p. 53.

${ }^{34}$ Debevoise, Ibid., p. 13. According to Rawlinson, the Seleucids were defeated by the Parths and retreated. George Rawlinson, Ibid., 1873, p. 49.

${ }^{35}$ Debevoise, İbid., p. 15.

${ }^{36}$ Brosius, Ibid., p. 85; Trevor Bryce, Ancient Syria: A Three Thousand Year History, Oxford University Press, Oxford 2014, p. 181. Molon extended its borders to the Euphrates (Firat) River and took the title of king with this rebellion.

\author{
History Studies \\ www.historystudies.net
}


order to establish his dominance over the eastern regions Seleucus King Antiochus Megas III initiated the Eastern Campaign (212/209-205 BC). ${ }^{37}$ After the king took over the lands of Armenia $^{38}$, he advanced towards Mesopotamia and Persia. ${ }^{39}$ Antiochus Megas III, who was advancing successfully in the east, moved towards Parthia but had to make a treaty in 205 BC due to the strong resistance of the Parthians. ${ }^{40}$ In accordance with the treaty, King Antiochus Megas III approved that Parthia was an official regional power. ${ }^{41}$

As a result of the Magnesia War between the Seleucid and Roman Kingdoms in 190 BC $^{42}$, in accordance with the Apameia Peace Treaty made between the two states in 188 BC, the Seleucids withdrew from Asia Minor and their borders were considerably narrowed. Thus, developments that shook the Seleucid domination in the East began to take place. ${ }^{43}$ By the time of Seleucus King Antiochus Epiphanes IV (175-164 BC), the King organized an expedition to dominate the Eastern lands and to stop the progress of the Parthians. Antiochus Epiphanes IV attacked Armenia over Euphrates and defeated the Armenian King Artaxias in 165 BC. ${ }^{44}$ However, in this period, due to Hellenization activities in Judah lands, a great rebellion (Maccabee Revolt) ${ }^{45}$ was encountered and the Seleucids lost their political power. ${ }^{46}$ The Parthian King Mithridates I (Arsakes V) (171-138 BC) bolstered his sovereignty in Parthia as of $160 \mathrm{BC}$ and became the first Parthian King that gained full independence against the Seleucids. ${ }^{47}$

\title{
2.The Kingdom of Parthia and its Struggles for Sovereignty against the Seleucid
}

Mithridates I (Arsakes V) captured Media in 148 BC and curbed the Seleucids' activity areas in the East. ${ }^{48}$ The acquisition of Media was seen as a factor that facilitated the passage of the Parthians to Mesopotamia and their domination in these fertile lands. ${ }^{49}$ Thus, the King moved towards Mesopotamia, Seleuceia Tigris (Seleuceia on the Tigris River) and Babylon in 141 BC. ${ }^{50}$ Seleucid King Demetrius Nicator II (145-141 BC/129-1225 BC), who was concerned about the expansion of the Parthians, organized an expedition against the Parthians in Mesopotamia in 141/140 BC, but he was defeated. Mithridates I captured Seleuceia Tigris and was crowned as the King of Parth in the city in $141 \mathrm{BC} .{ }^{51}$ At the same time, Mithridates I won a victory in Babylon and this success was recorded in Babylonian documents. ${ }^{52}$ The city of Babylon remained under

However, with the intervention of the Seleucid King Antiochus Megas III, Molon was repulsed and then he committed suicide in 220 BC. Arif Müfid Mansel, Ege ve Yunan Tarihi, Türk Tarih Kurumu Yayınları, Ankara 2014, p. 499.

${ }^{37}$ Boris Chrubasik, Kings and Usurpers in the Seleukid Empire: The Men who would be King, Oxford University Press, Oxford 2016, p. 35-36.

${ }^{38}$ Poly., 8. 23; Malcolm R. Errington, Hellenistik Dünya Tarihi MÖ 323-30, Çev: Gülşah Günata, 2. Basım, Homer Kitabevi, İstanbul 2020, p. 180.

${ }^{39}$ Bryce, Ibid., p. 186.

40 Justin, Epitome, 41. 5. 7; Debevoise, İbid., p. 18; Kaya, İbid., p. 122.

${ }^{41}$ Bivar, Ibid., p. 29.

${ }^{42}$ For detailed information on the war, see Appian., Syriake, 22; 33-36; Edwyn Robert Bevan, The House of Seleucus, Vol. 2, Edward Arnold Publisher, London 1902, p. 93-94; Mansel, İbid., p. 501-503.

${ }^{43}$ Bickerman, İbid., p. 6.

${ }^{44}$ Appian., Syriake, 45, 66; Debevoise, Ibid., p. 20.

45 For detailed information on this rebellion, see, Nurgül Yıldırım-Meltem Temizkan, "Seleukoslar Döneminde Antiokheia'da Sosyal ve Kültürel Yaşam Üzerine Analizler”, International Journal of Social Sciences and Education Research, 4, 4, 2018, p. 654-655.

${ }^{46}$ Mansel, Ibid., p. 505; Meltem Temizkan, Seleukoslar Döneminde Antiokheia (Antakya), (Hatay Mustafa Kemal Üniversitesi Sosyal Bilimler Enstitüsü, Master's Thesis), Hatay 2017, p. 46-47.

${ }^{47}$ George Rawlinson, Ibid., 1873, p. 95; Debevoise, İbid., p. 21, 29.

${ }^{48}$ Dabrowa, İbid., p. 169-170.

${ }^{49}$ Debevoise, Ibid., p. 21-22.

${ }^{50}$ Dabrowa, İbid., p. 169-170.

51 Debevoise, İbid., p. 22-23; Sherwin White- Kuhrt, İbid., p. 224; Brosius, İbid., p. 87.

${ }^{52}$ M. Rahim Shayegan, “On Demetrius II Nicator's Arsacid Captivity and Second Rule”, Bulletin of the Asia Institute, Vol. 17, 2003, p. 84; Errington, İbid., p. 270.

\author{
History Studies \\ www.historystudies.net
}


the rule of the Parths from approximately $141 \mathrm{BC}$ to $131 \mathrm{BC} .^{53}$ First of all, Media and then Babylon, which had strategic and commercial importance, were captured by the Parths, causing the Seleucids to weaken politically and economically in the Eastern lands. ${ }^{54}$

Seleucus King Demetrius Nicator II prepared for a new expedition to gain back the lands he lost. After successfully advancing and regaining some of the lost lands, Demetrius Nicator II was captured by the Parthians in 139/138 BC. As a captive, Demetrius Nicator II was taken to Hyrcania by Parthian soldiers. ${ }^{55}$ Seleucus King Demetrius Nicator II was married in Parthia to Rhodogune, the daughter of King Mithridates I. ${ }^{56}$ Mithridates I died in 138/137 BC and his son Phraates II (Farhad/VI Arsakes) (138-128 BC) came to the throne. ${ }^{57}$ When Mithridates I died, regions such as Hyrcania, Media and Babylon that strengthened the sovereignty of the Seleucids in the East were found within the borders of the Kingdom of Parthia ${ }^{58}$, and the dominance of the Seleucids in the East was shaken. Meanwhile, Antiochus Eurgetes/Sidetes VII (138-129 BC), the brother of Demetrius Nicator II, the ruler on Seleucus, organized a campaign against Parthia in 130 BC. ${ }^{59}$ King of Parthia Phraates II was defeated at the end of this expedition. Antiochus Eurgetes/Sidetes VII captured Seleuceia Tigris, and advanced to Media by enhancing his dominance in Babylon. Moreover, in 139/138 BC, he wanted his brother Demetrius Nicator II, who was detained by the Parths, to be released..$^{60}$ Demetrius Nicator II was freed and returned to the Seleucid Kingdom. ${ }^{61}$ However, the developments that followed engendered the problems that would lead to the disintegration and fragmentation of the Seleucid Kingdom over time. Antiochus Eurgetes/Sidetes VII was defeated and killed by the Parthians in 130/129 BC. ${ }^{62}$ Consequently, the absolute dominance of the Seleucids in Mesopotamia ended. ${ }^{63}$

With the loss of the territories in Asia Front, the Seleucids were restricted to the region between the west of the Euphrates and the Taurus Mountains.$^{64}$ Due to this failure, the Seleucids lost Persia and Babylon, and the Parthians expanded their field of activity. ${ }^{65}$ Furthermore, the Parthians moved their capital to Seleuceia Tigris, the ancient city of the Seleucids. ${ }^{66}$ Seleuceia Tigris was used both as a capital and a trade center during the Seleucid period. ${ }^{67}$

During the Seleucid period, economic activities were revived in Mesopotamia based on urbanization, and the population distribution was tried to be balanced within the framework of the Hellenization policy. At this point, the use of Seleuceia Tigris as a royal center during the Seleucid period also showed that the economic activities were primarily shifted to the Eastern lands, to the Tigris River by the Seleucids. ${ }^{68}$ The capture of this city by the Parths, just like

\footnotetext{
${ }^{53}$ Sherwin White- Kuhrt, İbid., p. 224.

${ }^{54}$ Gerassimos George Aperghis, The Seleukid Royal Economy, The Finances and Financial Administration of the Seleukid Empire, Cambridge University Press, Cambridge, p. 26.

${ }^{55}$ Debevoise, İbid., p. 23; Shayegan, İbid., p. 84.

${ }^{56}$ Appian., Syriake, 67; George Rawlinson, İbid., 1873, p. 96; Shayegan, İbid., p. 85; Bryce, İbid., p. 212.

${ }^{57}$ Frye, Ibid., p. 211.

${ }^{58}$ Debevoise, Ibid., p. 27.

${ }^{59}$ Shayegan, İbid., p. 90.

${ }^{60}$ Bryce, Ibid., p. 213; Errington, Ibid., p. 271.

${ }^{61}$ Debevoise, Ibid., p. 33.

${ }^{62}$ Justin, Epitome, 38. 10; Bryce, Ibid., p. 213. Appian recorded in his work that Antiochus VII committed suicide because of his failure. Appian, Syriake, 68.

${ }^{63}$ Aperghis, Ibid., p. 26.

${ }^{64}$ Sherwin White- Kuhrt, İbid., p. 229; Mansel, İbid., p. 505; Temizkan, İbid., p. 35; Halil Demircioğlu, Roma TarihiI. Cilt Cumhuriyet, Türk Tarih Kurumu Yayınları, Ankara 2019, p. 407.

${ }^{65}$ Errington, İbid., p. 271.

${ }^{66}$ Demircioğlu, Ibid., p. 407.

${ }^{67}$ Mansel, İbid., p. 519; Aperghis, İbid., p. 36. Following a west-centered policy, the Seleucids moved their capital from Seleukeia Tigris, first to Seleuceia Pieria (Çevlik/Samanda ğ/Hatay), and then to Antakya on the Asi (Asi) River in 300 BC. For details, see Temizkan, Ibid., p. 39-45.

${ }^{68}$ Aperghis, Ibid., p. 36-40.
}

\author{
History Studies \\ www.historystudies.net
}


Babylon, showed that the Seleucid dominance in Mesopotamian lands was weakened politically and socio-economically. The Parthians, who started to dominate in Mesopotamia, benefited from the functionality of the trade routes passing through Mesopotamia to strengthen their kingdom economically. ${ }^{69}$

The increase in the sphere of activity of the Parths was tried to be ensured by the control of the city of Babylon, which was located in the central regions of the kingdom in the period of Mithridates II (124/123-87 BC). Combined with their dominance in Babylon, the Parthians aimed to show that they were the absolute power on the Eastern side of the Seleucid Kingdom. ${ }^{70}$ Just like the Seleucids, it was understood that the Parthians also gave importance to the cities and tried to carry out socio-economic activities. ${ }^{71}$

As of 91 BC, it was understood that Demetrius Eucaerus III and his brother Philipp Epiphanes I were in a struggle for the throne in the Seleucus. It was revealed that the Parth's who were supporting Philipp Epiphanes I imprisoned Demetrius Eucaerus III and took him to Parthia. ${ }^{72}$ Thus, the Parthians showed that they were successful in politics by intervening in the domestic problems of the Seleucids.

The domination of the Parthians over the fertile lands between the Euphrates and Tigris was pinned by the Seleucids' struggle with Rome in the west. This process paved the way for the Parths to gather strength to fight Rome after the Seleucids. ${ }^{73}$ Here is Strabo's statement that the Parths could be considered as a rival to Rome, which expanded in the Western lands of the Seleucids:

"Arsaces and his successors first compelled Eucratides and his followers, and then the Scythians to give a part of Bactria to them. Now they dominate so many tribes in such vast lands that, in a way, they are defying Romans. Their way of life, their Scythian spirit and barbarian traditions are the secrets of their victory in battle and their success in ruling..."74

After the Seleucids, the meeting of the Parthians with the Romans, with whom they would enter into a great struggle for the Mesopotamian geography, took place in 92 BC through Sulla, the governor of Cilicia. ${ }^{75}$ Sulla met with Orobazos, the envoy of the Parthian King Arsaces, in Melitene (Malatya) on the banks of the Euphrates River. It was agreed that the aforementioned river should be the border between the two states. ${ }^{76}$ However, during the collapse of the Seleucids, the Romans saw themselves as their legitimate heirs and began to play an aggressive role in the Hellenic world. This situation was revealed through the following statements in the letter which was an offer of alliance against the Roman advance of the King of Pontos to the King of Parth before the Mithridatic War III (73-63 BC):

"Actually, there is only one rooted reason why the Romans waged war against all nations, peoples, and kings; their desire for dominance and wealth..." Therefore, they declared war against Philippos, the Macedonian king, whom they had treated as a friend as long as they were under the pressure of the Carthaginians; Then, when Antiochus came to his aid, they deflected

\footnotetext{
${ }^{69}$ Brosius, Ibid., p. 122.

${ }^{70}$ Frye, Ibid., p. 213; Brosius, Ibid., p. 90.

${ }^{71}$ Wilhelm Eilers, "Iran and Mesopotamia", The Cambridge History of Iran, 3/1, Ed. Ehsan Yarshater, Cambridge University Press, Cambridge 1983, p. 483-492.

72 Glanville Downey, A History of Antioch in Syria From Seleucus to the Arab Conquest, Princeton University Press, Princeton 1961, p. 135; Bivar, Ibid., p. 42.

${ }^{73}$ Debevoise, İbid., p. 28; Demircioğlu, İbid., p. 406-407.

${ }^{74}$ Strab., Geographika, XI. 9. 2; Sherwin White- Kuhrt, İbid., p. 86; Delil, İbid., p. 43-44.

${ }^{75}$ Frye, İbid., p. 214.

${ }^{76}$ Brosius, İbid., p. 91; Mehmet Kurt, "M.Ö. I. Yüzyılda Roma-Parth İlişkilerinin Kilikya Eyaleti’ndeki Yansımaları”, Uluslararası Avrasya Sosyal Bilimler Dergisi, 2, 2011, p 2; Ercüment Yıldırım, "Roma-Parth Mücadelesinde Firat Nehri’nin Jeopolitik Önemi”, Tarihin Peşinde-Uluslararası Tarih ve Sosyal Araştırmalar Dergisi, 7, 2012, p. 50-51.
}

\author{
History Studies \\ www.historystudies.net
}


him from his goal with the surrender of Asia. When they weakened Philippos, they captured his lands from Antiochus to the Taurus Mountains and his ten thousand talents..."

There were long-lasting wars due to territorial disputes between Rome, which started to consolidate its absolute sovereignty in Anatolia after 70s BC, and the Parthians, who would be border neighbors in the East from $64 \mathrm{BC} .{ }^{78}$ Especially the line between Syria and Mesopotamia and the control of the trade network stretching from Mesopotamia to Bactria were desired to be seized by both Rome and Parthians, and Mesopotamian lands became an important center of economic return. Keeping the Mesopotamian lands under control continued between Rome and Parth as well as the struggles between Seleucid and Parth. ${ }^{79}$

\title{
Conclusion
}

Mesopotamia, with its deep-rooted political and cultural tradition, as well as its trade and population volume, continued to be one of the centers of the Ancient Ages that needed to be seized and dominated permanently, even in the Hellenistic Period. Administrative structuring carried out over the provinces during the Persian period continued with the period of kingdoms established by Alexander and his commanders, where the borders were partially protected. The sovereignty of Mesopotamia and the surrounding provinces was tried to be preserved by the Seleucid Kingdom after Alexander. Preventing or curbing anti-Seleucus local political formations in Mesopotamia and its immediate surroundings has been determined as the main factor shaping the Eastern policy of the kingdom. In this context, it is understood that they organized expeditions against the Medes and especially the Parths, which damaged the absolute dominance of the Seleucid Kingdom in the region, and made agreements with these political elements when necessary. The Parths' attempt to take advantage of any weakness in the Seleucid Kingdom and the loss of their sovereignty in Babylon and Iran as a result of their heavy defeat by the Parths in 130 BC paved the way for the Parths to increase their political influence in these geographies. Especially with the political outlook that developed in favor of Rome, with the Seleucids starting to lose power in the Western lands, the Seleucid-Parthian struggle was replaced by the RomanParthian wars in Mesopotamia and its nearby geography.

\footnotetext{
77 Sall. Hist. 4.69.5 vdd.

${ }^{78}$ David Magie, Anadolu'da Romalılar. M.Ö. III. ve IV. Yüzyıllarda Batı Anadolu, Çev: N. Başgelen-Ö. Çapar, Arkeoloji ve Sanat Yayınları, İstanbul 2007, p. 55; Rose Mary Sheldon, Rome's Wars in Parthia Blood in the Sand, Vallentine Mitchell Publishing, London 2010, p. 14; Ercüment Yıldırım, İbid., p. 45-64.

${ }^{79}$ Colledge, Ibid., p. 23; Michael Burgan, Great Empires of The Past: Empires of Ancient Persia, Chelsea House Publishers, New York, 2010, p. 14; Delil, İbid., p. 48-49. See also, Peter M. Edwell, Between Rome and Persia, The Middle Euphrates, Mesopotamia and Palmyra under Roman Control, by Routledge, London 2008, p. 7-30.
}

\author{
History Studies \\ www.historystudies.net
}




\section{Bibliography}

APERGHIS, Gerassimos George, The Seleukid Royal Economy, The Finances and Financial Administration of the Seleukid Empire, Cambridge University Press, Cambridge 2004.

APPIANUS, Appian's Roman History, Translated by Horace White, VIII.II-XII, Cambridge, Mass. (The Loeb Classical Library), London 1912-1913.

ARRIANUS, The Anabasis of Alexander or The History of the Wars and Conquests of Alexander the Great, Translated by E. J. Chinnock, London 1883.

BEVAN, Edwyn Robert, The House of Seleukos, Vol. 1-2, Edward Arnold Publisher, London 1902.

BICKERMAN, Elias, "The Seleucid Period", The Cambridge History of Iran, 3/1, Ed. Ehsan Yarshater, Cambridge University Press, Cambridge 1983, p. 3-20.

BIVAR, Adam D. H., "The Political History Of Under The Arsacids", The Cambridge History of Iran, 3/1, Ed. Ehsan Yarshater, Cambridge University Press, Cambridge 1983, p. 2197.

BURGAN, Michael, Great Empires of The Past: Empires of Ancient Persia, Chelsea House Publishers, New York 2010.

BROSIUS, Maria, The Persians, by Routledge, New York 2006.

BRYCE, Trevor, Ancient Syria: A Three Thousand Year History, Oxford University Press, Oxford 2014.

CHRUBASIK, Boris, Kings and Usurpers in the Seleukid Empire: The Men who would be King, Oxford University Press, Oxford 2016.

COLLEDGE, A. R. Malcolm, The Parthians, Thames and Hudson, London 1967.

DABROWA, Edward, "The Arsacid Empire”, The Oxford Handbook of Iranian History, Ed. Touraj Daryaee, Oxford University Press Oxford 2012, p. 164-186.

DEBEVOISE, Neilson Carel, A Political History of Parthia, The University of Chicago Press, Chicago 1938.

DEMIRCİĞLU, Halil, Roma Tarihi-I. Cilt Cumhuriyet, Türk Tarih Kurumu Yayınları, Ankara 2019.

DELİL, Nefel Roma-Part Savaşları Işı̆̆ı̆nda Doğu Siyaseti ve Toprak-Sinır Mücadeleleri, (Dokuz Eylül Üniversitesi Sosyal Bilimler Enstitüsü, Master's Thesis), İzmir 2018.

DROYSEN, Johann Gustav, Büyük İskender Tarihi, Çev: Prof. Dr. Bekir Sitkı Baykal, Panama Yayınları, Ankara 2020.

DOWNEY, Glanville, A History of Antioch in Syria from Seleucus to the Arab Conquest, Princeton University Press, Princeton 1961.

DOWNEY, Glanville, Ancient Antioch, Princeton University Press, New Jersey 1963.

EDWELL, M. Peter, Between Rome and Persia, The Middle Euphrates, Mesopotamia and Palmyra under Roman Control, by Routledge, London 2008.

EILERS, Wilhelm, "Iran and Mesopotamia", The Cambridge History of Iran, 3/1, Ed. Ehsan Yarshater, Cambridge University Press, Cambridge 1983, p. 481-504. 
ERRINGTON, Malcolm R., Hellenistik Dünya Tarihi MÖ 323-30, Çev: Gülşah Günata, 2. Basım, Homer Kitabevi, İstanbul 2020.

FRYE, Richard Nelson, The History of Ancient Iran, C. H. Becksche Verlagsbuchhandlung, München 1983.

GRAINGER, D. John, The Syrian Wars, Leiden, Boston, Brill 2010.

JUSTINUS, Epitome of Pompeius Trogus, Philippic Histories, John S. Watson, 1853.

KAHRAMAN, Özgür Eskiçă̆ Tarihinde Parthlar, (İstanbul Üniversitesi Sosyal Bilimler Enstitüsü, Master's Thesis), İstanbul 2002.

KATOUZIAN, Homa, The Persians: Ancient, Medieval and Modern Iran, Yale University Press, New York 2010.

KAYA, Mehmet Ali, Türkiye’nin Eskiçağ Tarihi-III- Hellenistik Dönem, Bilge Kültür-Sanat Yayınları, İstanbul 2019.

KURT, Mehmet, "M.Ö. I. Yüzyılda Roma-Parth İlişkilerinin Kilikya Eyaleti'ndeki Yansimaları", Uluslararasl Avrasya Sosyal Bilimler Dergisi, 2, 2011, p. 1-14.

LERNER, D. Jeffrey, The Impact of Seleucid Decline on the Eastern Iranian Plateau: The Foundations of Arsacid Parthia and Graeco-Bactria, Franz Steiner Verlag, Stuttgart 1999.

MAGIE, David, Anadolu'da Romalılar. M.Ö. III. ve IV. Yüzyıllarda Batı Anadolu, Çev: N. Başgelen-Ö. Çapar, Arkeoloji ve Sanat Yayınları, İstanbul 2007.

MANSEL, Arif Müfid, Ege ve Yunan Tarihi, Türk Tarih Kurumu Yayınları, Ankara 2014.

POLYBIUS, The Histories, With an English Translation by W. R. Paton I-VI. Cambridge, Mass. (The Loeb Classical Library), London 1922 v.d.

RAWLINSON, George, The Sixth Great Oriental Monarchy or The Geography, History, \& Antiquities of Parthia, Longmans, Green \& Co., London 1873.

RAWLINSON, George, Parthia, T. Fisher Unwin, London 1893.

RAWLINSON, George, The Bactrian Empire Under the Greek Dynasties: Bactria from the Earliest Times to the Extinction of Bactrio-Greek Rule in the Punjab, Cambridge 1909.

SALLUST, Selections from the Histories, Translation by R. C. Rolfe, Harvard University Press, Cambridge (Mass.), 1921.

SHAYEGAN, M. Rahim, "On Demetrius II Nicator's Arsacid Captivity and Second Rule", Bulletin of the Asia Institute, Vol. 17, 2003, p. 83-103.

SHELDON, Rose Mary, Rome's Wars in Parthia Blood in the Sand, Vallentine Mitchell Publishing, London 2010.

SHERWIN WHITE, Susan-Amélie Kuhrt, From Samarkhand to Sardis: A New Approach to the Seleucid Empire, University of California Press, Berkeley-Los Angeles 1993.

STRABON, The Geography of Strabo, With an English Translation by Horace Leonard Jones I-VIII. London, (The Loeb Classical Library), New York 1917- 1932.

STROOTMAN, Rolf, "The Coming of the Parthians: Crisis and resilience in Seleukid Iran in the reign of Seleukos II", The Seleukid Empire, 281-222 BC: War Within the Family, Ed. K. Erickson, Classical Press of Wales, Swansea 2018, p. 129-150. 
TARN, William, Woodthorpe, The Greeks in Bactria \& India, Cambridge University Press, London 1938.

TEMİZKAN, Meltem, Seleukoslar Döneminde Antiokheia (Antakya), (Hatay Mustafa Kemal Üniversitesi, Sosyal Bilimler Enstitüsü, Master's Thesis), Hatay 2017.

TOSUN, Serhat Pir, Antik Çăg'da Doğu-Batı Mücadelesi Kapsamında Roma-Part İlişkileri, (Uludağ Üniversitesi Sosyal Bilimler Enstitüsü, Master’s Thesis), Bursa 2020.

YILDIRIM, Ercüment, "Roma-Parth Mücadelesinde Firat Nehri'nin Jeopolitik Önemi", Tarihin Peşinde-Uluslararası Tarih ve Sosyal Araştırmalar Dergisi, 7, 2012, p. 45-64.

YILDIRIM, Nurgül, "Çivi Yazılı Tarihçelerde Babil'in Doğulu Son Hâkimleri Parthlar”, 3. Uluslararası Multidisipliner Sosyal Bilimler Kongresi, 04-06 Mayıs 2021, Ankara 2021, p. 323-331.

YILDIRIM, Nurgül-Meltem Temizkan, "Seleukoslar Döneminde Yaşanan Suriye Savaşları Üzerine Bir Değerlendirme", Mustafa Kemal Üniversitesi Sosyal Bilimler Enstitüsü Dergisi, 14, 39, 2017, p. 117-131.

YILDIRIM, Nurgül-Meltem Temizkan, "Seleukoslar Döneminde Antiokheia'da Sosyal ve Kültürel Yaşam Üzerine Analizler", International Journal of Social Sciences and Education Research, 4, 4, 2018, p. 645-660.

WIESEHOFER, Josef, "Fars under Seleucid and Parthian Rule", The Age of the Parthians The Idea of Iran, Vol. 2, Ed. V. S. Curtis-S. Stewart, I.B. Tauris Publishing, London, New York 2007, p. 37-49. 